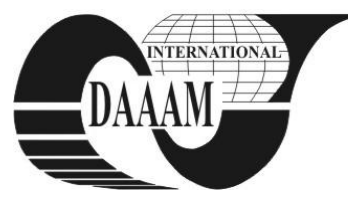

Annals of DAAAM for 2011 \& Proceedings of the 22nd International DAAAM Symposium, Volume 22, No. 1, ISSN 1726-9679 ISBN 978-3-901509-83-4, Editor B. Katalinic, Published by DAAAM International, Vienna, Austria, EU, 2011 Make Harmony between Technology and Nature, and Your Mind will Fly Free as a Bird Annals \& Proceedings of DAAAM International 2011

\title{
COST OF ACTIVITIES IN THE QUALITY COST ACCOUNT
}

\author{
KOLOSOWSKI, M[ariusz] \& CHWASTYK, P[iotr]
}

\begin{abstract}
The issue of the calculation of the activities cost in the quality management system in conditions of piece and small batch production has been presented in the paper. The prerequisites of using Activity Based Costing to calculate cost of production and processes in enterprise has been indicated. The model of quality assurance activities cost calculation has been worked out. The advantages of proposed solutions have been pointed out.

Key words: quality, cost, cost of quality, Activity Based Costing $A B C$, activity
\end{abstract}

\section{INTRODUCTION}

The competition strategy in present economy is based on aspiration for costs reduction, shortening the time of bringing a new product into the market and simultaneous assurance of products quality and functionality. Quality, as the product's ability to satisfy user's needs, is perceived as a crucial factor to enterprise's development strategy. Product's quality influences on both enterprise's incomes and costs. Economic dimension of quality level is the cost of quality calculation. That cost should be calculated very precisely. Tendencies in the market economy development, such as keener competition, closer cooperation and global market, require knowing exact values of all cost components related to manufacturing process, the total cost of manufactured products and, of course, the cost of quality of the production process.

The inconvenience of the traditional quality cost account is dividing cost of quality only to three main groups: cost of prevention, cost of appraisal and cost of failure. Such structure of the quality cost account makes difficult to recognize, which activities and processes in enterprise are responsible for generating particular cost. Yet, traditional methods of cost calculation are not always precise in assigning cost of quality to products and services, especially in conditions of piece and small batch production. That's why it is justified to use the Activity Based Costing (ABC) method to determine cost of quality as a part of the production costs. It is assessed that activities affected quality assurance absorb even more than $25 \%$ of enterprise's resources (Lunarski, 2008; Tsai, 1998). Therefore, streamlining the activities of the quality management system enables optimizing expenditures to achieve as high as possible quality or accepted quality reducing costs.

\section{ACCOUNTING THE COST OF QUALITY BASIS OF THE ABC METHOD}

The fundamental assumption of Activity Based Costing is that activities necessary to manufacture product are directly responsible for generating cost. Performed activities in enterprise may be defined using the Business Process Analysis. The results of this analysis are:

- selecting activities,

- establishing the activities outputs,

- establishing determining keys of the activities (activities outputs measures)
Activities of the production processes may be divided into direct and indirect activities. Direct activities participate in the production process route directly. Accounting cost of activities starts from the indirect activities, divided into levels, up to direct activities (Fig. 1). Cost of activity is assigned to other activities according to the number of units of its output measure.

Cost of resources is first assigned to cost cells and then to activities realized in enterprise according to proper keys of division. Calculating the product unit cost requires defining the set of activities that are necessary to manufacture and sell the product. Moreover, determining the number of units of each activity assigned to the product is indispensible. Evaluating the activity cost rate and total activity cost assigned to the product is based on formulas (1-3):

$$
\begin{gathered}
x_{i}=\frac{c_{i}}{U_{i}} \\
u_{i}=\sum_{w=1}^{W} u_{i w} \\
c_{i w}=x_{i} \times u_{i w}
\end{gathered}
$$

where:

$x_{i} \quad$ - activity $i$ cost rate,

$c_{i} \quad$ - activity $i$ cost,

$u_{i} \quad$ - number of units of activity $i$ output measure,

$u_{i w} \quad$ - number of units of activity $i$ output measure assigned to product $w$,

$c_{i w} \quad$ - activity $i$ cost assigned to product $w$.

The cost calculation model based on the ABC method has been described in (Kolosowski, 2008).

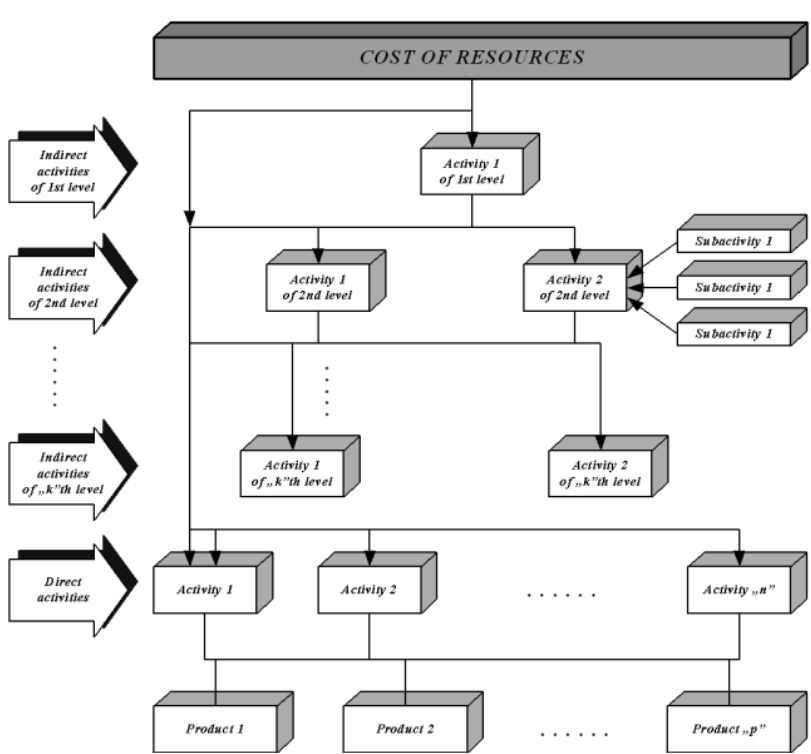

Fig. 1. General structure of the production process activities and accounting for their costs 


\section{QUALITY ASSURANCE ACTIVITIES}

The sequence of activities responsible for creating the product quality is usually presented as a quality loop. Exact calculation of cost of quality is very difficult, because indispensible data should be acquired from different cells in enterprise, deliverers and customers. A lot of components of quality cost interwine with other cathegories of cost, so separating them is possible only thanks to experience of the practitioners, because company's accounts does not itemize the cost of quality cathegory (Juran \& Gryna, 1980).

Gaining exact data of successive phases of the production process flow including stages related with forming the product quality is possibile only thanks to Activity Based Costing metod. The starting point of using this method is circumscribing activities connected with quality assurance. General structure of these activities in enterprises is presented in the fig. 2. Exemplary generic activities of quality assurance have been described in (Kołosowski \& Chwastyk, 2007).

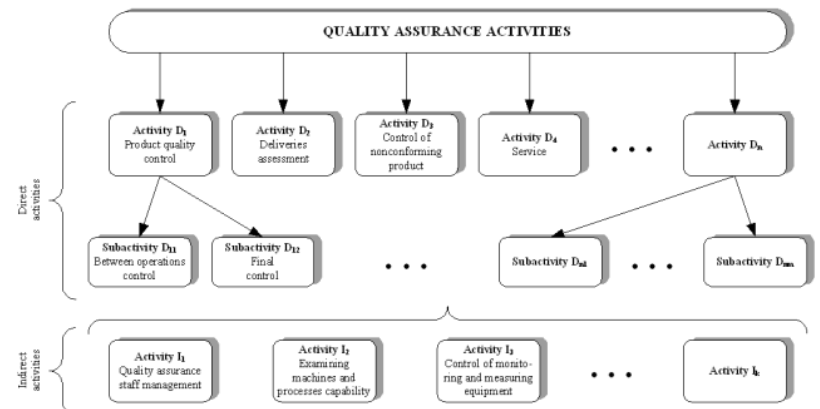

Fig. 2. General structure of quality assurance activities

Taking into consideration the way of calculating the cost of quality using the proposed model based on the $\mathrm{ABC}$ metod, activities in enterprises have been dividead into three groups:

- first group - its total cost is assigned to cost of quality,

- second group - a part of its cost is assigned to cost of quality,

- third group - activities connected with production process route, but its cost is not assigned to cost of quality at all.

\section{EXAMPLE}

The example of calculating cost of quality concerns production of a gear wheel $\left(\mathrm{z}=52, \mathrm{~m}_{\mathrm{n}}=2.0\right)$. Rolled bar is an input material. Volume of production is 50 units.

Processes in enterprises consist of a number of activities. Before defining activities processes costs, first the cost of the individual cost cell should be defined, that is why generic costs have been assigned to cost cells. To define this, factory accounting sheet, in which intermediate indicating costs are accounted for organizational units in enterprises, has been used. These costs have been accounted directly out according to consumption or indirectly according to proper keys of division. In production practice, one action is often made on many cost cells. In the balance sheet of actions for every cost cell one may isolate actions in which this particular cell takes part.

Then costs of cells have been assigned to activities. To calculate the product unit cost the set of activities necessary to manufacture and sell the product and the number of units of activities output measure assigned to the product have been defined. Activities cost rates and activities total costs assigned to the product have been determined basis of formulas (1-3).

The result of the calculation is presented in the table 1. Direct and indirect cost and product unit cost including cost of quality have been specified.

\begin{tabular}{|c|l|r|}
\hline No. & \multicolumn{1}{|c|}{ Cost } & $\begin{array}{c}\text { Value } \\
\text { [cost units] }\end{array}$ \\
\hline 1 & Material cost & 5452,35 \\
\hline \multirow{2}{*}{2} & Labour cost & 3605,36 \\
\cline { 2 - 3 } & inc. quality cost & 437,42 \\
\hline \multirow{2}{*}{3} & Internal failure cost & 365,50 \\
\cline { 2 - 3 } & inc. internal failure cost linked to product unit & 7,31 \\
\hline \multirow{2}{*}{4} & Indirect cost & 11260,75 \\
\cline { 2 - 3 } & inc. indirect quality cost & 1871,18 \\
\hline \multirow{2}{*}{5} & Total product self cost (50 units) & 20683,96 \\
\cline { 2 - 3 } & inc. quality total cost & 2674,10 \\
\hline \multirow{2}{*}{6} & Product unit cost & 413,68 \\
\cline { 2 - 3 } & inc. quality unit cost & 53,48 \\
\hline
\end{tabular}

Tab. 1. Cost calculation results

The foregoing calculation includes cost borne by enterprise by the time of delivering the final product to the customer. Then, the cost of service and warranty repair has to be taken into consideration too. This cost may be estimated or calculated after the period of guarantee and is constituted as cost of quality.

\section{CONCLUSION}

Activity Based Costing gains exact data of actual products costs, production processes and activities linked with the processes including quality assurances activities. ABC method may be a very usefull tool to determine product cost in piece and small batch production because of possibility of designing several alternative variants of the production process route and high share of indirect cost within production total cost. It is possible to calculate exact product cost and total quality cost for particular variants and choose the most rational one.

Running cost of quality account according to $\mathrm{ABC}$ method makes taking reasonable decisions connected with quality management. Analyzed processes realized in enterprises supply data to conduct cost calculation basis of ABC method. As a result we get a lot of information concerning the effectiveness of taken activities, amount of borne costs and processes and actions demanding improvement. This information is used in taking decisions linked with perfecting those processes in enterprise.

The main limitation of presented solution is necessity to gain a lot of data, so computer system of management in enterprise seems to be essential to implement proposed method.

\section{REFERENCES}

Juran, J.M. \& Gryna, F.M. (1980). Quality planning and analysis: From product development through use, McGraw-Hill, ISBN: 0070331782, New York

Kolosowski, M. (2008). Optimization of the Manufacturing Process Route of Machine Components Aided with Activity Based Costing. Annals of DAAAM for 2008 \& Proceedings of the 19th International DAAAM Symposium, Katalinic, B. (Ed.), pp. 717-718, ISBN: 978-3-901509-68-1, ISSN: 17269679, Trnava, Slovakia, October 2008, DAAAM International, Vienna, Austria

Kolosowski, M. \& Chwastyk, P. (2007). Quality assurances activities and their costs in the ABC method, In: Computer Integrated Management, vol. 1, Knosala R., (Ed.), pp. 434444, PTZP, ISBN: 978-83-923797-2-0, Opole

Lunarski, J. (2008). Quality management. Standards and principles, WNT, ISBN: 978-83-204-3281-7, Warszawa

Tsai W.-H. (1998). Quality cost measurement under activitybased costing. International Journal of Quality \& Reliability Management, Vol. 15, No. 7, pp.719-752, ISSN: 0265-671X 